\title{
Contracts and cooperation: The relative failure of the Irish dairy industry in the late
} nineteenth century reconsidered ${ }^{1}$

Ingrid Henriksen, * Eoin McLaughlin, ** and Paul Sharp ***

* Department of Economics and Business, University of Southern Denmark, Odense, Denmark, ing@sam.sdu.dk

** Department of Geography and Sustainable Development, University of St. Andrews, St. Andrews, Scotland, eoin.mclaughlin@st-andrews.ac.uk

\begin{abstract}
*** Department of Economics and Business, University of Southern Denmark, Odense, Denmark,pauls@sam.sdu.dk
\end{abstract}

Abstract: Why did the establishment of cooperative creameries in late nineteenth century Ireland fail to halt the relative decline of her dairy industry compared to other emerging producers? This paper compares the Irish experience with that of the market leader, Denmark, and shows how each adopted the cooperative organizational form, but highlights that an important difference was institutional: specifically regarding the enforcement of vertically binding contracts. We argue that this failure, combined with a strong proprietary sector which was opposed to cooperation, reinforced the already difficult conditions for dairying in Ireland due to poor social capital.

Keywords: Contracts, cooperation, dairying, Denmark, Ireland

JEL codes: K12, L31, N43, N53, Q13

\footnotetext{
${ }^{1}$ We express our gratitude to Ciara Pelly of the Irish Co-operative Organization Society for granting us access to the ICOS archive and to Michael Lynch, archivist of the Kerry library, for providing information relating to the McEllistrim family. We would also like to thank Graeme Acheson, Graham Brownlow, Chris Colvin, Vincent Comerford, Brian Heffernan, Markus Lampe, Cormac Ó Gráda, Kevin O’Rourke, John Turner and participants at the Economic History Society conference 2013, the Adelaide FRESH meeting 2013, the North East Conference on British Studies 2013, the 2014 Irish Quantitative History Meeting, and the European Social Science History Conference in Vienna 2014 for valuable comments and suggestions. Ingrid Henriksen gratefully acknowledges financial support from the Carlsberg Foundation and Eoin McLaughlin graciously acknowledges support from the Leverhulme Foundation.
} 


\section{Introduction}

Irish dairying experienced relative decline in the late nineteenth century. After thirty years of mechanization and twenty years of cooperation (the first Irish cooperative was established in 1889), the share of Irish butter on the British market became a fraction of what it had been during its heyday in the mid-nineteenth century. It declined from 46.6 per cent in 1860 to 11.9 per cent in 1910 (O'Rourke 2006), despite the supposed advantages of the cooperative organizational form. Thus, Solar (1990) estimates that the volume of Irish exports to Britain were stagnant, growing at -0.02 per cent p.a. from 1889-1910, even after the introduction of cooperatives. Separate trade data for Ireland begins in 1904, and as Figure 1 illustrates, the volume of exports over this period grew by 0.6 per cent per annum and the real value of Irish butter exports by 0.8 per cent per annum.

[Figure 1 about here]

The big winner on the British market was Denmark, which in contrast seems dramatically to have illustrated the advantages of embracing cooperation: Henriksen et al (2011) provide an econometric demonstration of this. The first cooperative was established in 1882, and Denmark's share of the British butter market increased from 0.6 per cent to 35.2 per cent over the same period. ${ }^{2}$ Even during the First World War, when the competition from Denmark was more or less cut off, Irish producers failed to exploit their temporary advantage (Meenan 1970).

The relative failure of Irish dairying requires some explanation, especially given her many historical and natural advantages in dairying. We argue here that an important explanatory factor lies with the difficulties experienced by Irish cooperatives when

\footnotetext{
${ }^{2}$ Australia, at 13.6 per cent, and Russia, at 11.9 per cent, were in second and third place respectively.
} 
attempting to enforce vertically binding contracts. Indeed, it is well known that the establishment of cooperative creameries, which fuelled the Danish success story, relied on the ability to enforce the supply of milk from member farmers. Although such vertically binding contracts were, as demonstrated by Henriksen et al (2012), not just legal but strictly enforced by the Danish courts, this was not the case in Ireland.

Comparing Ireland and Denmark purely on dairying grounds is somewhat misleading as the agricultural structure of both countries was significantly different (see e.g. Barrington 1926, pp 269-270). A greater emphasis was placed on livestock trading in Ireland and here Irish farmers held a significant share of the livestock trade, supplying 85 per cent of all British imports in the 1890s (Perren 1971). Also, Ireland's climate was different and dictated grass-fed cattle and militated against winter dairying (Ó Gráda 1994, 2006). Finally, TFP growth in Irish agriculture was a respectable 0.79-0.87 per cent per annum over the period 1890-1910 (Turner 1996, p. 138). Thus, our question is not so much about absolute failure but relative failure.

We seek to understand this by examining a number of important institutional and cultural differences between the two countries. In terms of the institutional framework for the cooperatives, in Ireland they were characterized by limited liability, ${ }^{3}$ which meant that shareholders did not have such a large financial stake in the enterprise, and were thus presumably also less concerned about potential failure. Moreover, if they unilaterally left the cooperative, they were not liable for any outstanding debts. This meant that the lack of a binding rule was even more of a problem. In terms of culture, previous work has demonstrated that there was a long tradition of cooperation in the countryside in Denmark ${ }^{4}$. Ireland did not, perhaps due to a relatively heterogeneous population which seems in general to have been an impediment to constructing cooperative institutions (O'Rourke 2007a). This heterogeneity was most obviously apparent in the fact that Ireland was divided between Catholics and Protestants, as well

\footnotetext{
${ }^{3}$ See also Guinnane and Martínez-Rodríguez (2010).

${ }^{4}$ See the full version of this paper: Henriksen et al (2015).
} 
as Irish and English speakers, whereas Denmark almost exclusively consisted of Lutheran Danish speakers. O’Rourke measures (lack of) social capital through the number of 'outrages' (i.e. crimes against persons or property) per 10,000 of population at the height of the Land Wars (1880-2), taken from Rumpf and Hepburn (1977, p. 52).

In fact, we argue that the lack of a binding rule might have reinforced the effects of poor social capital in Ireland and, combined with sub-optimal institutional arrangements, contributed to conflicts in the countryside, and the development of a bifurcated system of cooperative and proprietary creameries. Thus, there was pernicious competition for the finite milk supply, where farmers were continually looking for opportunities to supply their milk to a rival creamery, either cooperative or proprietary, for a higher price. This competition was between cooperatives in the north of the island, and more often with incumbent proprietary creameries as well as cooperatives in the south. Thus, unlike in Denmark, the Irish cooperatives failed to outcompete the proprietary creameries. ${ }^{5}$

Our story illustrates the endogeneity of organizational choice, a choice that reflects the prevailing social, cultural, economic and institutional context of individual countries. ${ }^{6}$ Guinnane et al (2007, p. 691), in their study of the evolution of choice of organizational structure, argued that business people have different ways to adapt to contracting problems which are compatible with the prevailing legal regimes in which they operate. We find evidence of such adaptability as both cooperative and proprietary creameries attempted to circumvent the lack of vertically binding contracts by providing loans to suppliers with the explicit proviso that repayment be in kind (milk). However, this market based approach was second best (inefficient) compared to a vertically binding contract as borrowers were able to ignore this and repay in cash when it suited them.

\footnotetext{
${ }^{5}$ See Gibbons (2000) for a discussion of the literature on the 'mess', caused by for example conflicting interests, which may cause organizations to perform sub-optimally.

${ }^{6}$ Here we draw on Posner (2010)'s discussion on the distinction between institutional and organizational economics.
} 
We do not claim that binding and poor social capital was the only reason for the relative decline of Irish dairying. Clearly, other factors, such as cow density and farm size may also have affected the capacity of cooperatives to function as in Denmark. However, these are not mutually exclusive and there may have been interactions between them: for example low cow density may have created incentives to undermine binding contracts. Yet, to assess the relative contribution of each factor is difficult as the question is not only quantitative, in terms of milk input and butter output, but it is inherently qualitative in terms of the same, as well as in the quality and enforcement of contracts. Our methodology is qualitative; we look to the records of court proceedings, where Irish producers attempted to enforce similar contracts to those used in Denmark, as well as to the thoughts of contemporaries on this matter. But we also refer readers to quantitative studies (Ó Gráda 1977; O’Rourke 2007a, 2007b) and show how our findings, a heretofore neglected aspect of the Irish experience, may offer nuanced insights into existing research on cooperation in Ireland.

The remainder of this paper proceeds as follows. Section 2 discusses the theoretical framework from institutional economics within which we place the debate about cooperation in Ireland vis-à-vis Denmark. Section 3 surveys the literature on binding contracts in the latter, and Section 4 explains how they failed in the former. Section 5 explores the implications of this and section 6 concludes. $^{7}$

\section{Towards an institutional explanation of the relative failure of Irish dairying}

In common with Henriksen et al (2012), the present analysis is conducted within the framework offered by Williamson and the 'new institutional economics'. This can be conceptualized as illustrated by Figure 2. The first three levels must function before firms can find success at the fourth level, where they simply have to profit maximize.

\footnotetext{
${ }^{7}$ A longer version of this paper is available: see Henkriksen et al (2015).
} 
[Figure 2 about here]

O'Rourke (2007a) suggests that the failure to cooperate in Ireland was due to a lack of social capital owing to her sectarian divisions, and thus focuses on the first level. Denmark's homogeneous population after the loss of its German-speaking minority in the Second Schleswig-Holstein War of 1864 obviated such concerns there. Such focus on social capital is becoming increasingly common in studies of cooperatives - see e.g. Beltrán Tapia (2012) and Garrido (2014) for some recent contributions.

Ostrom, looking at many case studies, has concluded that large-scale cooperation can be amassed gradually from below: 'Once a group has a well-functioning set of rules, it is in a position to collaborate with other groups, eventually fostering cooperation between a large number of people. Formation of a large group at the outset, without forming smaller groups first, is more difficult.' (Economic Sciences Prize Committee 2009). This observation is, of course, not uncommon. Other comparative studies of cooperation in Ireland and Denmark have pointed out the difference in the way the two movements originated: as we will discuss they were imposed from above in the Irish case, but emerged from below (sometimes in the face of hostility from the agricultural establishment) in the case of Denmark. In fact, Danish cooperatives, beside the supportive interpretation of contract law, were also able to cooperate at higher levels of aggregation: that is, cooperatives could cooperate with one another at the local, the regional, and at the national level. Only thirteen years after the establishment of the first cooperative dairy in 1882 a large regional association was formed, and in 1899 a countrywide association of all types of rural cooperatives was founded.

Moving beyond the role of social capital, Henriksen et al (2012) look to the second and third levels, where Denmark stands out as a country where both the 'formal rules of the game' and the 'play of the game' worked in her favor: not only was it legally possible to write binding contracts, but penalties for breaking them were also enforced when 
evoked. Here we investigate the second and third levels for the case of Ireland, and find that binding contracts were not enforceable. In both countries the courts of law were the ultimate third party enforcers of the contractual agreements between a cooperative and the individual member, but in the Irish case the law more often than not decided against the interest of the cooperative. As Figure 2 suggests, there is a feedback from each institutional level to the previous one, so the failure at lower levels can have a negative effect on the first, thus potentially leading to a deterioration of social capital, something which there is plenty of evidence to suggest might have been the case in Ireland (see for example McLaughlin and Sharp 2015a).

\section{The importance of binding vertical contracts for cooperative creameries in Denmark}

As Henriksen et al make clear, the contracts made by individual cooperative creameries in Denmark, together with the support they received from the legal system, played an important role for the success of the dairy industry in that country. In particular, they argue that the entry condition for a creamery, i.e. the decision of whether or not to establish it in the first place, depended on its expected viability - and this depended on whether the milk supply of members could be enforced (Henriksen 1999, Henriksen et al 2012, p. 203). Of the various terms in these contracts, the binding rule is described by them as the most important. They explain that exit by a member threatened the survival of the creameries in three different ways: first, by increasing average costs, given the large fixed costs of establishing a creamery; second, since members were jointly liable for the loan to establish a creamery, exit would increase the liability of those who remained; and third, it affected the feasibility of transport routes between members and dairies. Thus, all bar two creameries in their sample of 49 for which they have complete records of the statutes from establishment regulated exit (Henriksen et al 2012, pp. 2023).

An indicator of their importance is that such contracts were prevalent from the beginning of the cooperative movement in Denmark. Unfortunately, the earliest statutes 
seem to be lost, but many examples from 1886 on are saved for posterity, and reveal various degrees of punishment for exit. Moreover, if the cases went to court, the cooperatives enjoyed support from the judiciary. Other cases were resolved amicably (Henriksen et al 2012, p. 214-15). The story was, however, very different in Ireland, where farmers either failed to cooperate with each other, or even if they formed cooperatives, these often became rivals.

\section{The cooperatives in Ireland}

\subsection{The Irish Agricultural Organisation Society}

From the late 1880 s onwards, the modern industrial creamery system was introduced in Ireland and at the same time the novel method of industrial organization, cooperation, was also applied to the Irish dairy industry and led to increases in productivity in dairy regions (Ó Gráda 1994, p. 259; O’Rourke 2007b; Bielenberg 2009). The adaption of cooperation as an organizational form was spearheaded by Horace Plunkett (1854-1932) and Robert Andrew Anderson (1860-1942) and their creation the Irish Agricultural Organisation Society (IAOS), formed in 1894. Their efforts were explicitly modelled on Scandinavian counterparts, notably Danish and Swedish. Particular emphasis was placed on introducing both innovations in Munster, the historic heartland of the Irish dairy industry and location of the so-called 'Golden Vale', but from the mid-1890s efforts began to introduce the combined innovations in the north of the island. From its establishment, the IAOS was a top down promoter of cooperation, and the Irish experience thus, as noted above, contrasted greatly with that of the Danish, where cooperatives were formed by voluntary associations of peasants. ${ }^{8}$ According to Horace Plunkett (1905, p. 192), the IAOS was expected not just to support existing cooperatives but also to 'create' cooperatives, and even to 'persuade' people to adopt cooperation (BPP 1892).

\footnotetext{
${ }^{8}$ See Colvin and McLaughlin (2014) for discussion of the role of the IAOS in establishing credit cooperatives.
} 
Somewhat incredibly however, given that Denmark was their inspiration, it was not until 1902, eight years after the establishment of the IAOS and 13 years after the establishment of the first cooperative creamery by Plunkett and Anderson in 1889, that a binding rule was introduced in the standard contract they provided for new cooperative creameries.

\subsection{The early evolution of the binding rule and limited liability}

There was, perhaps, a more general ignorance in the UK of the importance of the binding rule. For example, the British government was all too aware that Irish dairying was being outcompeted by continental competition, and commissioned a number of reports into the matter. These demonstrate clearly that they were also cognizant of the more general importance of contracts in cooperatives. As an illustration, a report commissioned by the British Board of Agriculture in 1893 gives an example of the 'Articles of association' of a Danish cooperative creamery (as well as for Swedish and German counterparts). The contract (one of many examples in Bøggild 1887) included a binding rule, but although much is made of the technological requirements in the contract (competence of the manager, cleanliness etc.), there is no mention of the legal side (Board of Agriculture 1893, pp. 9-13).

As mentioned above, however, the IAOS did eventually recognize the importance of the binding rule, introducing it in the standard contract they provided for new cooperatives in 1902:

'XX. Any member who shall without the consent in writing of the committee supply milk to any creamery other than that owned by the society for the space of three years from the date of his admission to membership, shall forfeit his shares, together with all money credited thereon.'

The penalty to the farmer was thus limited to the loss of his share in the creamery, which was probably not such a disincentive to finding alternative buyers for his milk, 
since he was presumably not interested in cooperating anyway (see the discussion below on unlimited liability). Moreover, as noted by McCabe (1906, pp. 561-562), even these rules were 'declared non enforceable at law in Ireland'.

From a somewhat small base in the 1890s the number of cooperatives numbered 83 in 1897 and tripled to 247 in 1902. By this time, the IAOS began to recognize the weakness of the 1902 rule relative to the rules operated in Denmark, and stated already in its annual report from 1902 that the 'it would be very wise for societies to adopt a rule similar to the fundamental rule of the Danish co-operative dairy societies, definitely binding their members under penalty to supply the milk of a definite number of cows for a certain period. The general adoption of this [binding] rule in Denmark has tended more than anything else to the stability of the Danish Dairy societies' (IAOS 1902, p. 20). By the end of 1908 there were 292 societies in Ireland (17 were formed in 1908 but there were also 13 dissolutions), and it was at last decided to adopt a new, stricter, binding rule, which greatly increased the penalty for disloyalty, and aimed to make 'the delimitation of the area over which the creamery operates... become an accepted principle' (IAOS 1908, p. 7). The new rule was as follows:

'Rule 5a: ...each milk-supplying member shall, so long as he remains a member of the society, deliver to the society's creamery on every working day, all the milk produced from his cows (except such as may be required for use in his household)... and any member who shall fail to do so shall pay to the society (as liquidated damages and not as penalty) the sum of one shilling per cow per day for every cow's milk not so delivered...'

Members were made aware of the rule as it was published on the back of their shares and also in the society rule books. ${ }^{9}$ Note that this rule, despite the intentions of the IAOS as revealed by the above quotes, did not in fact specify 'a certain period' or specify the

\footnotetext{
${ }^{9}$ Letter Riddal to IAOS, 10 April 1908, Tipperary Co-operative Creamery Ltd, ICOS archive 1088/887/1, NAI; Coolmoyne and Fethard rules, Registry of Friendly Societies archive R957, NAI.
} 
'area over which the creamery operates'. As we discuss below, this shortcoming was to form the basis of a raft of legal challenges, which ultimately made it unenforceable.

In fact, this was perhaps an even bigger problem in Ireland than it would have been in Denmark, since a major difference between cooperatives in the two countries was that the Irish cooperatives were characterized by limited liability (Brabrook 1898, p. 140, Gosden 1973, p. 202). The organizational choices available did not permit the permutation of unlimited liability and the ability to trade ${ }^{10}$ - effectively this meant that members paid a nominal value for their share of the cooperative, and if it went into liquidation they stood to lose only to the value of their shareholdings (McGrath 2003, p. 26). Shares were partially paid up, usually a quarter, and the remainder was held in reserve until such time as a society was required to call on its shareholders. ${ }^{11}$ The intention was that shares would be purchased for every cow that a member possessed and that the first instalment would be in cash and the remaining instalments in milk (IAOS 1895, p. 19). Liability of members in a dairy cooperative was thus limited to the amount they held in shares within the society. As Table 1 shows, share capital in cooperative creameries made up approximately 55 per cent of creamery liabilities, and the remainder was borrowed from banks. ${ }^{12}$

[Table 1 about here]

Anderson later argued that the limited liability of cooperative creameries under the Industrial and Provident Societies Acts meant that they were hampered by a lack of share

\footnotetext{
${ }^{10}$ Alternatives were limited liability companies or unlimited liability friendly societies, however the latter did not have trading powers.

${ }^{11}$ Shares issued by cooperatives with a maximum of $£ 200$ share value.

${ }^{12}$ Bank borrowing created a problem as the Irish Joint Stock Banks did not recognize cooperatives as a legal person but instead had individual members guarantee bank loans. This feature of creamery capitalization had the inadvertent effect of de-mutualizing cooperative creameries.
} 
capital, thus leading to a greater reliance on bank loans, which in turn were secured by guarantees of two members of the cooperative committee rather than the cooperative itself (Anderson 1935, pp. 160-162). In Denmark, however, loan capital made up more than 70 per cent of the capital invested, suggesting again that it was the principle of unlimited liability joint and several for the loans, mainly in savings banks, which had the binding effect (see Henriksen et al 2012 pp. 215-16). As Anderson also noted, he believed the individual farmers saw their subscriptions as 'more in the light of a subscription to a worthy object than as an investment in a business... If his liability, in the event of a failure, had been made greater he might, and probably would have taken a keener interest in the undertaking.' (Anderson 1935, pp. 167-168).

\subsection{The cooperatives in court: Attempts to enforce the stricter binding rule}

As discussed by Henriksen et al (2012), it did not matter whether or not the binding rule was enforceable, if members did not attempt to flout it. In Denmark, the rule certainly was tested, however, and this was also the case in Ireland. Henriksen et al (2012, p. 218) state that binding vertical contracts were illegal under Common Law, but the situation seems to have been somewhat more nuanced. In fact, according to Dempster (1997, p. 337), with a few esoteric exceptions, there was not a single case where an exclusive dealing contract had been held unenforceable as a restraint of trade before 1912.

This situation changed, however, with a judgment from the Irish Court of Appeal in the case of Tipperary Co-operative Creamery Society Ltd v Hanley, ${ }^{13}$ subsequently upheld by the House of Lords. Although the King's Bench Division had ruled against Hanley, this decision was reversed. The case concerned a farmer, Hanley, who although a member of the Tipperary Cooperative, had never supplied milk to them, contrary to Rule 5a above.

\footnotetext{
13 'Tipperary Co-operative Creamery Society Ltd v Hanley, 1912.' The Irish Reports, 1912 vol II: King's Bench Division, pp 586-605.
} 
Correspondence between the Tipperary cooperative and the IAOS reveal their opinion of the importance of the case and the binding rule. In a letter to Delaney, secretary of the Tipperary Co-operative Creamery, regarding the initial court case, R.A. Anderson wrote that 'the rule to which the County Court Judge has taken exception in such an emphatic manner was drafted by Counsel. It has stood the test of a considerable number of cases in which the creameries suing their members have invariably won their cases and I would refer you to recent cases in Co. Limerick where Judge Law Smith upheld the rule and gave decrees.... The matter is one of great importance not only to your society but to many of the others which are similarly circumstanced and you may depend upon the IAOS doing everything in its power to have the law on the subject clearly laid down (our emphasis). ${ }^{14}$ The importance of the rule was also emphasized by Charles Riddall, local organizer for the southwest, who, in a letter to R.A. Anderson, stressed that 'you perhaps don't realize how much interest is being taken in this case throughout the South where the rule in question is operative, and how great the issue is that hangs on it; it means life or death for some Societies. ${ }^{15}$ Later that year, R.A. Anderson wrote that the IAOS would 'if necessary agitate in conjunction with the Co-op Union for an amendment to the Industrial \& Provident Societies Act so as to give Irish Co-op societies the power which co-operators in other countries enjoy and which is the foundation of their movements. ${ }^{16}$ Tellingly, R.A. Anderson believed that Cleeve's, the largest proprietary creamery, was sponsoring Hanley's action because he had been supplying milk to Cleeve's, and this belief seems confirmed by subsequent events, as discussed below. ${ }^{17}$

Thus, in the appeal of the case, the Tipperary Cooperative argued forcefully that the rule was 'of vital importance to a Creamery Society' and that 'in the absence of such a

\footnotetext{
${ }^{14}$ Letter R.A. Anderson [IAOS secretary] to Delaney [secretary of Tipperary Co-operative Creamery], 4 July 1911. Tipperary Co-operative Creamery Ltd, ICOS archive 1088/887/1, NAI.

${ }^{15}$ Letter Riddal [IAOS organizer] to R.A. Anderson [IAOS secretary], 4 June 1912, Tipperary Co-operative Creamery Ltd, ICOS archive 1088/887/1, NAI.

${ }^{16}$ Letter IAOS secretary to Fant, 26 June 1912. Tipperary Co-operative Creamery Ltd, ICOS archive 1088/887/1, NAl.

${ }^{17}$ Irish Times, 25 April 1912; Letter from Anderson to Sealey [IAOS Counsel], 1 May 1912.
} 
rule the creamery could not reckon on having the material necessary to carry on its operations'. Moreover, they argued it was 'mutually beneficial', since while the cooperative was ensured a supply, so was the farmer secured a buyer for his milk. They also argued that it was 'a matter of voluntary contract. No one is compelled to become a member of the society; but if he does so, he knows that there are rules which will become binding on him, and he can read them before he becomes a member.'

Hanley argued with equal vigor against the rule, explaining that it was 'uncertain', 'unintelligible', and had 'no limit as to time or distance'. The Court of Appeal, and subsequently the Lords, concurred. Since the rules did not allow for the voluntary withdrawal of a member, except by transferring his shares which required the consent of the committee, and since they did not define 'milk-supplying member', they were found to be an illegal restraint of trade and an unreasonable one. The judgment stated that 'There can be, as it appears to me, no question as to the restraint of trade involved. The public inconvenience is plain. We are dealing with one of our fundamental and natural foods, and the admitted consequence of a large success on the part of the society would be to expose the public generally to obvious difficulty in obtaining a necessary and usual food for all people, and particularly for the young'. They are particularly critical of the poor drafting of the rule, explaining that it 'ought to have been carefully and skillfully prepared, and should not have been left, or been attempted to be enforced, in its present form... It has a scope and operation altogether beyond what is reasonable for the protection of the society'.

The Lords suggested a way to rewrite the rule so that it would be acceptable: 'there would be no objection to a rule that members, in addition to paying the price of their shares, should continue to sell to the society the milk of such cattle as are fed within a specified distance, for a limited period. A regulation of this kind would be reasonable, and the same result might be obtained in other ways.'... 'An intelligent draftsman would have little difficulty in preparing rules adequate to protect the society without placing unreasonable restrictions and obligations upon the members.' 
The IAOS was quick to comply with this suggestion, and asked their barrister to redraft the rule (IAOS 1913, pp. 10-11). The new rule stated that:

'Rule 6(2): ... no individual member of the society, ... who shall have milk to sell, the produce of a cow or cows kept or grazed on lands within the area defined in Rule 5, shall, without the written consent of the committee first obtained, sell any such milk to any creamery other than a creamery of the society, or to any company, society, person, or person who sell milk or manufacture butter for sale. Any member of the society committing a breach of this rule shall pay to the society, as and for liquidated damages, and not by way of penalty, the sum of one shilling per cow per day for every cow's milk sold contrary hereto.'

This rule was swiftly implemented by cooperatives across the country, and the IAOS, in their annual report from 1913, stressed again that the "binding rule" is not aimed, as it may seem, at coercing members to support their society, but at bringing home to them in a practical way their obligations to themselves, to their neighbors who are co-operating with them, and to their society' and that it 'is also expressly directed against the evil of overlapping which inevitably turns societies that ought to be living in harmony with each other into greedy competitors... who... are not co-operators but who are prepared to sell their milk to the creamery which offers the highest bid...' (IAOS 1913, pp. 10-11). In the same report, the IAOS stated 'that proceedings to enforce compliance... may be taken' (IAOS 1913, pp. 10-11).

In fact, the IAOS cherry picked cases to fight, as can be seen from a series of communications between R.A. Anderson and Charles Riddall. ${ }^{18}$ They finally settled on the Athlacca Co-operative creamery in Limerick, and agreed to pay Counsel's fees conditional

\footnotetext{
18 There was a contemporaneous case in Charleville, Co. Cork and Anderson wrote to Riddal stating 'that the [IAOS] Committee will await your selection of the society to which you consider the IAOS ought to render assistance in prosecuting any legal proceedings under this rule' R. A. Anderson to Riddal -24 September 1913 - Re Binding Rule Charleville Society, Athlacca Creamery, ICOS archive 1088/15/3, NAI.
} 
on the amendment of their statutes. ${ }^{19}$ Initial judgments supported the change. A judgment in 1914, Athlacca creamery v Houlihan, led James Fant, IAOS Organizer, to write to Andersen that this 'pretty well establishes the validity of the binding rule which now may go unchallenged ${ }^{20}$. Then in 1915 Athlacca Co-Operative Creamery Ltd., v. Lynch again ruled in favor of the new rules. However, already in in 1916 a significant episode of litigation came with Coolmoyne \& Fethard Co-operative Creamery Ltd v Bulfin. ${ }^{21}$

The farmer, Bulfin, had applied for shares in the creamery under the previous binding rule 5 , but after the rules were changed (apparently without his knowledge), he decided to stop supplying milk to the creamery, his reason being that he could get higher prices elsewhere. The cooperative thus sued him under rule 6(2) for $£ 20$ damages for breach of contract. Bulfin argued that the rules were a restraint of trade and injurious to the public, but the cooperative successfully argued that the new rules explicitly took account of the previous case. The King's Bench Division and the Court of Appeal ruled that the new rule was not an illegal restraint of trade, or against the public interest. The judgement recognized explicitly that the rule had been rewritten in response to Tipperary Cooperative Creamery Society Ltd $v$ Hanley.

The case was then taken to the House of Lords, who concurred. Interestingly, although they were bound by the previous judgment, questions were actually raised about whether it had been correct or not. As they state, the 'agreement undoubtedly contained a restraint on individual trading, but it by no means follows that such a restraint is a "restraint on trade" within the legal meaning of the term'. Nevertheless they

\footnotetext{
${ }^{19}$ In the Athlacca case there were several defaulters but only one member was pursued because it was believed that 'Edmund Houlihan's case is one with no flaw in it' (C. C. Ridall - report on Athlacca Cooperative Creamery - 11 Nov 1913). Also, see Letter R.A. Andersen to Riddall, 24 September 1913, 16 October 1913, and 25 October 1913. Letter John J. Breen (Athlacca secretary) to R. A. Anderson, 15 Oct 1913. Letter Anderson to Coleman, 29 April 1913: Athlacca Creamery, ICOS archive 1088/15/3, NAI.

${ }^{20}$ Letter Fant to R.A. Andersen, 4 March 1914. Athlacca Creamery, ICOS archive 1088/15/3, NAI.

21 'Coolmoyne \& Fethard Co-operative Creamery Ltd v Bulfin, 1916'. The Irish reports, 1917, vol II: King's Bench Division, pp 107-137. See Tipperary Co-operative Creamery Ltd, ICOS archive 1088/887/1, NAI \& 'Coolmoyne and Fethard dairy society' R 957, NAI Friendly Societies, for a copy of the rule 5a.
} 
were obliged to accept that 'So long as the decision of the Court of Appeal stands, such an agreement is, in Ireland, both illegal and void'. There is discussion about whether the new rule took care of both objections in the former case, namely the lack of well specified geographical area and the absence of any time limit to the obligation. But importantly, and with parallels to similar judgments in Denmark (see Henriksen et al 2012), the judge noted explicitly the importance of the rule being upheld:

'... if each member is to be left to act as it pleases himself in the matter of sales, it is doubtful if a new venture of the sort could succeed at all. It is not a general restraint on competition. Any person can compete. It is merely an agreement entered into between several persons of full age, and aware of what they are doing, that they will not individually sell to a competitor of the whole, so as to injure the business belonging to all.'

Legislative action did not cease, however. A similar case, McEllistrim $v$ Ballymacelligott Co-operative Agricultural \& Dairy Society Ltd., ${ }^{22}$ was ruled on in the House of Lords in $1919 .{ }^{23}$ The case itself was contemporaneous to the Coolmoyne case and was discussed in correspondence between the IAOS and its legal representatives and it was decided to focus on the Coolmoyne case as 'Ballymacelligott can wait'. ${ }^{24}$ This cooperative had also altered its rules, so that they were identical to those declared legal above, but McEllistrim objected to the new wording and impeached its validity. The cooperative initially lost the case, since the judge ruled that the previous case rested on the farmer having agreed to the rules. The cooperative committee then decided to associate the IAOS with the case, since it is one of vital importance to the whole

\footnotetext{
22 'McEllistrim v Ballymacelligott Co-operative Agricultural \& Dairy Society Ltd', The Irish Reports 1918, vol 1: Chancery Division, pp 313-338; 'McEllistrim (appellant) and Ballymacelligott Co-operative Agricultural \& Dairy Society Ltd (respondents)', House of Lords Ireland [1919], A.C. 548-605.

${ }^{23}$ See also Doyle 2013, p. 171.

${ }^{24}$ IAOS secretary to Carrigan [K.C.] - 20 Dec 1916; Anderson to Barry [solicitor, Cashel], 5 April 1916: Coolmoyne and Fethard, ICOS archive 1088/263/6, NAI.
} 
movement' (IAOS 1917, p. 11). It thus turned into a battle between the IAOS and large proprietary creameries. ${ }^{25}$

The IAOS was initially triumphant when the Court of Appeal reversed the judgment and held that the rule was binding, since the change was lawfully made. But it was eventually overturned in the House of Lords, where it was declared that the rules 'imposed upon members a greater restraint than was reasonably required for the protection of the society'. For reasons which are not at all clear, the new contract, although meeting one of the demands made after the Tipperary vs. Hanley case, namely that the geographical area covered by the cooperative was well specified, did not limit the duration of the binding rule in terms of time.

Anderson (1935, pp 170-171) later recalled the struggle to enforce the binding rule, and believed that '...if we had limited to a definite period, I think the appeal would have been dismissed.' It is thus difficult to conclude anything other than that the cooperatives in Ireland failed due to the poor draftsmanship of their lawyers rather than obstacles put in place by the legal system as such. Why the IAOS failed to such an extent can only be speculated upon. One factor might have been purely financial: the IAOS was dependent on donations from member societies, many of which seemed to have been reluctant to fund it (the archives of the IAOS are full of copies of letters informing members that their subscriptions were overdue). Perhaps they were simply unable to afford good legal advice, a point which is noted explicitly in correspondence between the IAOS and the Coolmoyne Committee. Apparently the Coolmoyne case had 'more than absorbed all that was provided for in the way of legal expenses for the year'. ${ }^{26}$ In any case, the decision in 1919 introduced into English law the idea that an exclusive dealing contract was a restraint of trade (Dempster 1997, p. 338). ${ }^{27}$

\footnotetext{
${ }^{25}$ Described as 'opponents of the Co-operative movement' by Anderson when retrospectively discussing the McEllistrim case (1935, pp. 170-171).

${ }^{26}$ Anderson to Barry, 16 December 1916, Coolmoyne and Fethard, ICOS archive, 1088/263/6, NAI.

27 According to Dempster (1997, p. 339) the House of Lords decision was made per incuriam, since it
} 


\section{The result of no binding: The competition for milk supply in Ireland}

Anderson argued that the combination of limited liability and the uncertainty surrounding the binding rule meant that a farmer was 'interested... in hawking his milk supply from his own creamery to some competing concern - alas, often misnamed cooperative' (Anderson 1935, pp. 167-168). However, from reading their annual reports, the IAOS before Irish independence seems to have measured the extent of its achievements largely through the number of cooperatives established whether or not they ended up competing against each other. As Table 2 illustrates, in these terms, they were successful, and the cooperative share of production gradually increased. ${ }^{28}$

[Table 2 about here]

Denmark never had a large proprietary sector and the competition mostly consisted of traditional landed estates or small 'community creameries' founded in the 1870s (McLaughlin and Sharp 2015b). However, in Ireland private creameries retained an important share, particularly in Munster, which was also the center of dairying. Here the private sector was dominated by the public company, the Condensed Milk Company of Ireland Ltd., 'Cleeve's', which was a large purchaser of milk and a large-scale exporter of canned condensed milk and, during the First World War, an important supplier of the British military (Bielenberg 2009, p. 75). Cooperatives in the province were also the predominant contributor to the recorded output of the IAOS, at roughly double the cooperative output in the rest of Ireland (Bolger 1977, p. 183).

neglected to cite a previous binding case, Taff Vale Railway Co v Macnabb, which provided the former definition of restraint of trade.

${ }^{28}$ Although the numbers are certainly inflated, because cooperatives which ceased operations were not immediately deleted from the registers. 
Map 1 - a snapshot of the situation in 1908 - illustrates the end result. Creameries clustered at opposite ends of the country, with cooperatives competing largely against each other in the north, and largely against proprietary creameries in the south. Note the absence of creameries across the center of the island, which was due to the aforementioned livestock trade. The competition meant that creameries could not be ensured a regular supply of milk, owing to the absence of a functioning binding rule.

[Map 1 about here]

In fact, the nature of the non-cooperatives shown in Map 1 is also more complex than a cooperative versus non-cooperative narrative might suggest. Many of the large jointstock creameries opened branches and these were predominantly located in the southwest of the island in the Golden Vale and, according to Porter (n.d./1909), 'many of the smaller joint-stock, though not strictly co-operative, are mostly owned and worked by the milk suppliers'. It is possible to address this by using the records of dissolved companies. ${ }^{29}$ We searched the typeset catalogue of dissolved companies reconstituted after 1924, held in the national archives of Ireland, for words such as 'butter', 'dairy' and 'creamery'. This search yielded 23 companies, of which a number were not creameries but wholesalers or general producers.

[Table 3 about here]

\footnotetext{
${ }^{29}$ Companies registered in Ireland were required to submit annual shareholder returns to the Dublin office of the Registrar of Companies. Original company records were destroyed by a fire in the Custom House in 1921 during the Irish War of Independence. Following the destruction of the original material all companies in the Irish Free State were required to re-submit their details.

http://www.irishstatutebook.ie/1924/en/act/pub/0021/ - We thank the authors of Acheson et al (2014) for making us aware of this source.
} 
The records of the creameries varied in consistency, but many contained information on shareholder name, address, occupation and shareholder value, and some also contained the memorandum of association and articles of association. For the companies, the records also show what happened upon dissolution. The records found are summarized in Table 3. The list contains not only the largest indigenous 'creamery', Cleeve's, but also a number of smaller companies. The list also contains a number of companies that later converted into Industrial and Provident Societies (i.e. cooperatives). An interesting finding from Table 3 is the average shareholding in and participation of farmers as shareholders in each company, showing that large companies, in terms of capitalization, had less shareholders and few if any farmer shareholders, whereas smaller companies had more shareholders and a larger share of farmers as shareholders, thus confirming Porter's statement.

This brings up the issue, in terms of the organizational structure in Ireland, of what exactly it meant to be a cooperative or proprietary creamery. Many of the proprietary enterprises looked very much like the cooperative societies, which themselves were not functionally equivalent to cooperatives in the Danish sense, due to the absence of the 'fundamental' binding rule. Thus, although the absence of competition from large incumbent proprietary creameries was an important factor behind the cooperative success in Denmark, to characterize the problem merely as such would be to oversimplify the difficulties faced. In fact, as Bolger (1977, p. 205) noted, this problem was just as pronounced, 'regrettably, between co-ops themselves.'

To illustrate this, we need only look at the history of the Tipperary Co-operative Creamery (the society involved in litigation cited above). When it was first founded R. A. Anderson wrote to the secretary of the Tipperary society stating that 'I rather fear that the proposed site is too close to Greenane Cooperative Agricultural and Dairy society to prevent overlapping and to ensure a proper milk supply.' It later transpired that the chairman of the Greenane Society, Fr. Murphy, presided at the preliminary meeting of 
the Tipperary Co-operative creamery. Fr. Murphy later assured Riddal that 'a co-op creamery in Tipperary would not be in competition with any creamery but Cleeve's local factory, of which the people declare themselves tired' and that the 'binding rule was unanimously adopted, and the committee will have the option of refusing milk of any member who may have supplied it to any creamery than that or those by the society at any time.' Later Riddal wrote to R. A. Anderson that with 'the members being all legally bound to supply their milk, I feel confident that the society will be a great success, and will hit Cleeve severely. ${ }^{30}$ It seems therefore that the IAOS was not only careless about allowing cooperatives to have overlapping districts, but also actively promoted a turf war with the proprietary operators, and seems to have over-estimated the expected viability of its cooperatives in the presence of both proprietaries and cooperatives.

The proprietary operators responded in kind, however, and the annual reports of the IAOS made continual reference to the competition between creameries for milk supplies. For example, in 1899 it was stated that competition led to creameries paying a higher price for milk (IAOS 1899, pp. 15-16). Such 'overpricing' was presumably motivated by a desire to exploit economies of scale, and potentially even to cause the rival to fold, thus leading to the capture of even more suppliers. The support of large proprietary creameries such as Cleeve's for the bids to flout the binding rule might also suggest that some cross-subsidizing was going on to make this possible, at least in the private creamery sector.

Even after the first binding rule was introduced in 1902, complaints were often made about the problems of competing creameries in the IAOS reports. In 1907 reference was made to the practice of 'milk grabbing' resulting from overlapping boundaries as a result of competition between cooperatives (IAOS 1907, p. 6, p. 26), and the report from 1916 expresses surprise that completion between cooperatives continues in districts where there is a common proprietary competitor to fight' (IAOS 1916, p. 42) - again reflecting

\footnotetext{
${ }^{30}$ Letter IAOS secretary to Joseph Delaney, 2 April 1908; letter Riddal to Delaney, 3 April 1908; Riddal to IAOS 10 April 1908; Letter Riddal to R. A. Anderson, 27 April 1908: Tipperary Co-operative Creamery Ltd, ICOS archive 1088/887/1, NAI.
} 
the belligerent tone of the IAOS. In fact, the aforementioned Coolmoyne creamery was with the full knowledge of the IAOS placed so as to capture milk supply from Cleeve's, according to correspondence we found between Riddall and Anderson. ${ }^{31}$

This competition had pernicious effects on the whole industry. We found examples of creameries sometimes being forced to accept poor quality milk out of fear of a loss of supply: competition thus manifested itself both in terms of prices offered as well as in the quality they were prepared to accept. The IAOS continually exhorted creamery managers to implement quality control policies but these were difficult to enforce as a result of competition as rivals undercut policies (e.g. IAOS 1905, p. 3, IAOS 1906, p.7, IAOS 1907, p.5). Perhaps also Cleeve's condensed milk required less stringent quality controls than butter production. Anderson (1935, p.236) later recalled creameries finding objects such as straw and fish heads in milk when it was strained and noted that 'I frequently found that greater strictness as to condition of the milk was enforced in the cases of those suppliers whose farms were adjacent to the creamery than in the cases of those suppliers who lived on the outer edge of the creamery area and had another creamery, just as near, where they might expect more laxity. The neighboring suppliers had no alternative and could therefore be dealt with more firmly'. Thus, creameries, due to competition from both proprietary and cooperative creameries, implemented differential pricing with farmers furthest away receiving a higher price than those closest to the creamery (IAOS 1916, p. 42, IAOS 1919, p. 11). In fact, the Free State government rationalized the dairy industry under the auspices of the Dairy Disposal Board in the 1920s (see Breathnach 2000, pp 169-170) explicitly with the motivation to avoid competition between creameries. $^{32}$

There were alternatives to the binding rule of course. One was through government legislation, but this seems to have been politically unacceptable for most places before

\footnotetext{
${ }^{31}$ Report on Coolmoyne proposed co-operative creamery, letter C. C. Riddall to R. A. Anderson, 26 July 1909. Coolymoyne and Fethard Creamery, ICOS archive 1088/263/1, NAI.

32 P. Hogan, Minister of Agriculture, Memorandum on cooperation, 5 January 1927., Department of an Taoiseach Files NAI\S 5213
} 
the twentieth century, with the exception of New Zealand in 1894 (Brooking 1996). Ireland singularly failed to enact similar legislation, despite intense debates, until the 1920s (Johnson 1985, pp 11-12). Another was to issue loans to suppliers in return for a commitment to supply milk.

Historically, butter merchants in Cork 'advanced money to the people' on the condition that they 'required a monopoly of their butter.' ${ }^{33}$ This tradition, it seems, was also attempted by creameries at the turn of century. The British Cooperative Wholesale Society (CWS) attempted, as outlined by Redfern (n.d. [1913], pp. 302-303), to use loans, amounting to $f 0.5$ million, to tie-in a regular milk supply and the chief condition of lending was that borrowers should pledge their milk in repayment', as did smaller jointstock creameries (see Table 3), who regularly included credit to suppliers as assets in their audited annual accounts. Cooperative creameries also tried to use loans to tie in members, although the IAOS was suspicious of the practice as 'little better than the old system of money-lending by butter merchants, which held the dairy farmers of the South of Ireland in bondage' (IAOS 1909, p.9). Besides, this system met of course with difficulties owing to the fluctuating prices of butter and thus the value of the repayments, and was in sharp contrast to the situation in Denmark, where we have found evidence of only two cases where Danish cooperative creameries granted small short loans to members, plus a few cases in which members were running a deficit, when the purchase of butter and cream exceeded the value of the raw milk delivered. Lending as such was never seen as a task of the cooperative creameries, and was not necessary due to a functioning binding rule.

Ultimately, it seems safe to conclude that a well-functioning binding rule would have obviated many of the problems faced by the Irish cooperatives. Without it, they were not able to compete with their larger and richer proprietary counterparts, and were, demonstrably, not a superior organizational form in Ireland. However, without binding

\footnotetext{
${ }^{33}$ E.g. see exchanges between Daniel O'Connell (M.P. and director of the National Bank) and Piers Mahony (solicitor of the Provincial Bank of Ireland) at the select committee on Joint Stock Banks in the 1830s (BPP 1837, Q. 3997).
} 
conflict was exacerbated. Nothing helps to illustrate this more than the violent events after the decision of the House of Lords on 25 August 1919, which saw the destruction of the rival proprietary creamery, Slattery \& Sons (see McLaughlin and Sharp 2015b). The lack of a binding rule reinforced already poor social capital, in contrast to for example the Netherlands, which although similarly divided in religious terms was able to create parallel cooperative organizations along religious lines (Colvin and McLaughlin 2014).

\section{Conclusion}

We have taken up again the argument that the failure of Irish dairying relative to Denmark (and later competitors) was due in large part to a failure of cooperation. We focused on the difficulties caused by the inability to bind suppliers, which might have been due to and in turn reinforced poor social capital. Thus there was a vicious circle in Ireland, compared perhaps to a virtuous circle in Denmark. We cannot demonstrate that this was the reason why there were fewer cooperatives in Ireland, but we suggest that if they were not superior as an organizational from, then their emergence was at least less likely. The lack of a binding rule seems largely to be due to the incompetence of the IAOS and their Counsel, which ultimately led to its defeat in the courts. Thus, in Ireland the cooperative organizational form struggled to compete with private forms and the market was divided between both, unlike in Denmark, which was overwhelmingly cooperative.

We have emphasized the legal deficiencies here, but we believe that the impact of this on social capital needs more work. The aforementioned study by Garrido on irrigation communities in eastern Spain demonstrates that seemingly well-functioning cooperatives that had existed for centuries still could fail to create 'a culture of trust'. In the Spanish case cooperating at the marketing level could potentially have presented a great advantage for the export of oranges. A totally different angle is proposed by Glaeser et al (2002) who use an investment model to analyze an individual's incentive to invest in social capital and find that time horizons are extremely important: when individuals have a high probability of mobility they are less likely to invest in social capital. 
The reason for this is intuitively clear, but we cannot prove that the far higher emigration from Ireland compared to Denmark during the period we look at had an impact on cooperation. 


\section{References}

ACHESON, G. G, G. CAMPBELL, J.D. TURNER, and N. VANTEEVA. (2014). 'Corporate ownership and control in Victorian Britain.' Queen's University Centre for Economic History Working paper series, 14-01.

ANDERSON, R. A. (1935). With Plunkett in Ireland: the co-op organiser's story. Reprint, 1983, Dublin: Irish Academic Press.

BARRINGTON, T. (1926). 'A review of Irish agricultural prices'. Journal of the Statistical and Social Inquiry Society of Ireland 14, pp. 249-80.

BELTRÁN TAPIA, F.J. (2012). 'Commons, Social capital, and the emergence of agricultural cooperatives in early twentieth Spain'. European Review of Economic History 16:4, pp. 511-528.

BIELENBERG, A. (2009). Ireland and the industrial revolution: the impact of the industrial revolution on the Irish economy. London: Routledge.

BOARD OF AGRICULTURE (1893). Reports on Dairy Farming in Denmark, Sweden, and Germany. London: HMSO.

BØGGILD, B. (1887) Andelsmælkerier: Meddelser, samlede og bearbejdede. Copenhagen: Philipsen.

BOLGER, P. (1977). The Irish co-operative movement: its history and development. Dublin: Institute of Public Administration.

BPP (various years). Agricultural Statistics of Ireland. London: HMSO.

BPP (1837). Report from the Secret Committee on Joint Stock Banks; together with the minutes of evidence, appendix and index. (531). 
BPP (1892). Report from the Select Committee on Money Lending; together with the proceedings of the committee, minutes of evidence, appendix and index, paragraphs 1973, pp 101-102, (260).

BRABROOK, E. W. (1898). Provident Societies and Industrial Welfare. London: Blackie and Son.

BREATHNACH, P. (2000). 'The evolution of the spatial structure of the Irish dairy processing industry'. Irish Geography , 32:2, pp 166-184.

BROOKING, T. (1996). Lands for the People? The highland clearances and the colonisation of New Zealand. Otago: University of Otago Press.

COLVIN, C. L. and E. MCLAUGHLIN (2014). 'Raiffeisenism abroad: why did German cooperative banking fail in Ireland but prosper in the Netherlands?' Economic History Review 67:2, pp. 492-516.

DEMPSTER, H.L. (1997). Restraint of Trade at Common Law. PhD thesis in Law, University of Auckland.

DOYLE, P. J. (2013). 'Better, Farming, Better Business, Better Living: The Irish Co-operative Movement and the Construction of the Irish Nation-State, 1894-1932'. History PhD thesis, University of Manchester.

THE ECONOMIC SCIENCES PRIZE COMMITTEE OF THE ROYAL SWEDISH ACADEMY OF SCIENCES (2009). 'The nomination of Elinor Ostrom for the Nobel Prize in Economic Science', pp. 8-14.

GARRIDO, S. (2014). 'Plenty of trust, not much cooperation: Social capital and collective action in early twentieth century eastern Spain. European Review of Economic History 18:4, pp. 371-397.

GIBBONS, R. (2000). 'Why Organisations are such a mess (and what an economist might do about it). Mimeo. 
GLAESER, E.L., D. LAIBSON and B. SACERDOTE (2002). 'An Economic Approach to Social Capital'. Economic Journal 112, pp. 437-458.

GOSDEN, P.H.J.H. (1973). Self-help: Voluntary associations in nineteenth-century Britain. London.

GUINNANE, T., R. HARRIS, N.R. LAMOREAUX, J. ROSENTHAL (2007). 'Putting the Corporation in its Place'. Enterprise and Society 8:3, pp. 687-729.

GUINNANE, T.W. and S. MARTÍNEZ-RODRÍGUEZ (2010). 'Did the Cooperative Start life as a Joint-Stock Company? Business law and Cooperatives in Spain, 1869-1931'. Yale Economics Department Working paper No. 81.

HENRIKSEN, I. (1999) 'Avoiding Lock-In: Cooperative Creameries in Denmark, 1882-1903.' European Review of Economic History 3:1, pp. 57-78.

HENRIKSEN, I., M. LAMPE, and P. SHARP (2011). 'The Role of Technology and Institutions for Growth: Danish Creameries in the late Nineteenth Century.' European Review of Economic History 15:3, pp. 475-493.

HENRIKSEN, I., M. HVIID, and P. SHARP (2012). 'Law and Peace: Contracts and the Success of the Danish Dairy Cooperatives.' Journal of Economic History 72:1, pp. 197-224.

HENRIKSEN, I., E. MCLAUGHLIN and P. SHARP (2015). 'Contracts and cooperation: the relative failure of the Irish dairy industry in the late nineteenth century reconsidered'. EHES Working Paper no. 71.

IAOS (various years). Annual Reports of the Irish Agricultural Organisation Society, Ltd. Dublin.

JOHNSON, D. (1985). The interwar economy of Ireland. Dundalk: Dundalgan Press.

MCCABE, D.A. (1906). 'The Recent Growth of Co-Operation in Ireland.' Quarterly Journal of Economics 20:4, pp. 547-74. 
MCGRATH, S. (2003). Company law. Dublin: Thomson Roundhall.

MCLAUGHLIN, E. and P. SHARP (2015a). "'A Higher Tribunal than the House of Lords': the McEllistrim family, the IAOS and the slippery slope to co-operative development in Ireland'. (Mimeo).

MCLAUGHLIN, E. and P. SHARP (2015b). 'Competition between organisational forms in Danish and Irish dairying around the turn of the twentieth century', St. Andrews Environmental Economics Discussion papers, 2015-16.

MEENAN, J. (1970). The Irish Economy since 1920. Liverpool: Liverpool University Press.

Ó GRÁDA, C. (1977). 'The Beginning of the Irish Creamery System, 1880-1914.' Economic History Review 30:2, pp. 284-305.

Ó GRÁDA, C. (1994). Ireland: A New Economic History. Oxford: Clarendon Press.

Ó GRÁDA, C. (2006). 'Irish agriculture after the Land War.' In S. ENGERMAN and J. METZER (eds.). Land rights, ethno-nationality and sovereignty in history. London: Routledge.

O'ROURKE, K.H. (2006). 'Late 19th Century Denmark in an Irish Mirror: Land Tenure, Homogeneity and the Roots of Danish Success,' in J.L. CAMPBELL, J.A. HALL and O.K. PEDERSEN (eds.), The State of Denmark: Small States, Corporatism and the Varieties of Capitalism, Montreal: McGill-Queen's University Press, pp. 159-196.

O'ROURKE, K. (2007a). 'Culture, Conflict and Cooperation: Irish Dairying before the Great War'. Economic Journal 117, pp. 1357-1379.

O'ROURKE, K. (2007b), 'Property rights, politics and innovation: creamery diffusion in pre1914 Ireland'. European Review of Economic history, 11, pp 395- 417.

PERREN, R. (1971). 'The North American Beef and Cattle Trade with Great Britain, 18701914'. Economic History Review 24:3, pp. 430-444. 
PLUNKETT, H. (1905). Ireland in the new century with an epilogue in answer to some critics. Popular Edition (revised). London: John Murray.

PORTER, J. (n.d/1909 British Library). Porter's guide to the manufactures and shippers of Ireland, Belfast. Davidson and M'Cormack, first edition.

POSNER, R. A. (2010). 'From the new institutional economics to organisation economics: with applications to corporate governance, government agencies, and legal institutions.' Journal of Institutional Economics 6, pp 1-37.

REDFERN, P. (n.d., 1913). The Story of the C.W.S.: The jubilee history of the Co-operative Wholesale Society limited 1863-1913. Manchester: The Co-operative Wholesale Society Limited.

RUMPF, E. and A.C. HEPBURN (1977). Nationalism and Socialism in Twentieth-Century Ireland. Liverpool: Liverpool University Press.

SOLAR, P. M. (1990). 'The Irish Butter Trade in the Nineteenth Century: New Estimates and Their Implications.' Studia Hibernica 25, pp. 134-161.

TURNER, M. (1996). After the Famine. Irish Agriculture, 1850-1914. Cambridge: Cambridge University Press.

WILLIAMSON, O.E. (2000). 'The New Institutional Economics: Taking Stock, Looking Ahead.' Journal of Economic Literature 38:3, pp. 595-613. 


\section{Archival sources}

Beder-Malling Lokalhistoriske Arkiv, Malling, Denmark

Department of an Taoiseach Files, National Archives of Ireland

Dissolved company files, National Archives of Ireland

Friendly Society Archive, National Archives of Ireland

Irish Cooperative Organisation Society Archive, National Archives of Ireland 
Table 1: IAOS creamery membership and liabilities, 1906

\begin{tabular}{|l|c|c|c|c|c|}
\hline & Ulster & Munster & Leinster & Connacht & Ireland \\
\hline Membership & 19,741 & 6,896 & 2,247 & 11,834 & 40,718 \\
\hline Paid-up Share capital (f) & 52,880 & 34,183 & 11,030 & 19,736 & 117,829 \\
\hline Loan Capital (f) & 45,995 & 31,316 & 8,499 & 9,671 & 95,481 \\
\hline Total capital (f) & 98,875 & 65,499 & 19,529 & 29,407 & 213,310 \\
\hline Share capital per member (f) & 2.68 & 4.96 & 4.91 & 1.67 & 2.89 \\
\hline Mean membership & 190 & 90 & 107 & 455 & 179 \\
\hline Mean paid-up share capital (f) & 513 & 438 & 525 & 705 & 512 \\
\hline Mean loan capital (f) & 447 & 402 & 405 & 358 & 417 \\
\hline Mean total capital (f) & 960 & 851 & 930 & 1,089 & 936 \\
\hline $\begin{array}{l}\text { Mean share capital per member } \\
\text { (f) }\end{array}$ & 3.66 & 6.27 & 4.72 & 1.73 & 4.41 \\
\hline
\end{tabular}

Source: IAOS annual report 1906 
Table 2: Creameries in Ireland, 1892-1908

\begin{tabular}{|c|c|c|c|c|c|c|}
\hline Year & Ireland & $\begin{array}{c}\text { Proprietary } \\
\text { share of } \\
\text { creameries }\end{array}$ & $\begin{array}{c}\text { Cooperative } \\
\text { share of } \\
\text { creameries }\end{array}$ & $\begin{array}{c}\text { Munster } \\
\text { share of } \\
\text { creameries }\end{array}$ & $\begin{array}{c}\text { Proprietary } \\
\text { share in } \\
\text { Munster }\end{array}$ & $\begin{array}{l}\text { Cooperative } \\
\text { share in } \\
\text { Munster }\end{array}$ \\
\hline & Number & $\%$ & $\%$ & $\%$ & $\%$ & $\%$ \\
\hline 1892 & 175 & 76.57 & 23.43 & 75.43 & 73.48 & 26.52 \\
\hline 1893 & 190 & 75.79 & 24.21 & 79.47 & 72.19 & 27.81 \\
\hline 1894 & 226 & 73.01 & 26.99 & 77.43 & 70.29 & 29.71 \\
\hline 1895 & 255 & 75.69 & 24.31 & 80.39 & 75.61 & 24.39 \\
\hline 1896 & 279 & 74.19 & 25.81 & 80.29 & 75.89 & 24.11 \\
\hline 1897 & 324 & 73.77 & 26.23 & 77.16 & 79.20 & 20.80 \\
\hline 1898 & 387 & 57.36 & 42.64 & 71.83 & 68.35 & 31.65 \\
\hline 1899 & 480 & 63.33 & 36.67 & 66.04 & 79.18 & 20.82 \\
\hline 1900 & 506 & 62.45 & 37.55 & 65.81 & 79.88 & 20.12 \\
\hline 1901 & 547 & 62.16 & 37.84 & 63.62 & 80.75 & 19.25 \\
\hline 1902 & 584 & 75.17 & 24.83 & 62.50 & 84.66 & 15.34 \\
\hline 1903 & 612 & 79.25 & 20.75 & 62.42 & 81.41 & 18.59 \\
\hline 1904 & 609 & 75.04 & 24.96 & 62.40 & 81.32 & 18.68 \\
\hline 1905 & 791 & 67.89 & 32.11 & 59.04 & 79.23 & 20.77 \\
\hline 1906 & 780 & 55.77 & 44.23 & 61.15 & 76.52 & 23.48 \\
\hline 1908 & 644 & 48.91 & 51.09 & 56.83 & 70.22 & 29.78 \\
\hline
\end{tabular}

Sources: Agricultural Statistics of Ireland and Porter (n.d./1909). 
Table 3: Dissolved companies

\begin{tabular}{|c|c|c|c|c|c|c|c|c|}
\hline Company & Creamery & $\begin{array}{l}\text { Share capital } \\
\text { (f) }\end{array}$ & $\begin{array}{l}\text { Share } \\
\text { holders }\end{array}$ & $\begin{array}{c}\text { Average } \\
\text { share } \\
\text { Holding (f) }\end{array}$ & Farmer \% & Incorporated & $\begin{array}{l}\text { Converted to } \\
\text { IPS }\end{array}$ & $\begin{array}{l}\text { Liquidated/ } \\
\text { wound up }\end{array}$ \\
\hline Ballingarry dairy company & $\mathrm{Y}$ & 1127 & 147 & 7.67 & 92.52 & $5 / 5 / 1896$ & $19 / 02 / 1926$ & - \\
\hline Condensed Milk company of Ireland & $\mathrm{Y}$ & 350000 & 26 & 14000.00 & 0 & & & $13 / 11 / 1923$ \\
\hline Castlecor Dairy Company & Y & 887 & 75 & 11.83 & 89.33 & $18 / 3 / 1890$ & $11 / 08 / 1927$ & \\
\hline $\begin{array}{l}\text { Irish creameries \& exporters } \\
\text { association }\end{array}$ & - & - & - & - & - & - & - & - \\
\hline Drangan co-operative creamery & $\mathrm{Y}$ & 444 & 81 & 5.48 & 91.36 & 29/10/1897 & $31 / 07 / 1933$ & \\
\hline Bandon co-operative stores & Gen & 4000 & 7 & 571.43 & 28.57 & 14/12/1899 & & $15 / 03 / 1938$ \\
\hline Golden Vein dairy companies & $\mathrm{Y}$ & 9000 & 9 & 1000.00 & 0 & $16 / 07 / 1900$ & & $19 / 10 / 1938$ \\
\hline Newmarket dairy company & $\mathrm{Y}$ & 20878 & 27 & 1304.56 & 12.50 & $30 / 04 / 1904$ & & $22 / 06 / 1935$ \\
\hline Irish dairymen & $\mathrm{N}$ & 10000 & 18 & 588.24 & 0 & $30 / 07 / 1919$ & & 28/08/1931 \\
\hline Ballimena Dairy Company & $\mathrm{Y}$ & 2000 & 2 & 1000.00 & 50.00 & $08 / 03 / 1920$ & & $30 / 11 / 1925$ \\
\hline Ballyhay dairy company & $\mathrm{Y}$ & 665 & 39 & 17.97 & 83.78 & & $12 / 12 / 1923$ & \\
\hline Buttevant dairy company & Y & - & - & - & - & - & 25/06/1924 & \\
\hline Churchton dairy factory company & $\mathrm{Y}$ & 791 & 52 & 15.82 & 57.69 & & 29/11/1924 & \\
\hline Galbally dairy company & $\mathrm{Y}$ & - & - & - & - & - & 08/03/1922 & \\
\hline Cork Farmers Milk emporium & Gen & 4870 & 195 & 25.23 & 99.48 & $29 / 09 / 1921$ & $30 / 01 / 1935$ & \\
\hline
\end{tabular}




\begin{tabular}{|c|c|c|c|c|c|c|c|c|}
\hline United Irish counties milk producers & - & - & - & - & - & - & - & - \\
\hline Irish creamery company Itd & $\mathrm{N}$ & 2 & 1 & & & $21 / 04 / 1923$ & & 09/03/1928 \\
\hline $\begin{array}{l}\text { Condensed Milk Company of } \\
\text { Ireland (1924) Itd }\end{array}$ & $\mathrm{Y}$ & 85000 & 14 & 7894.74 & 0.00 & $16 / 02 / 1924$ & & $25 / 04 / 1927$ \\
\hline Puritas Milk Products company & Milk & 250 & - & & & $12 / 03 / 1927$ & & $26 / 10 / 1927$ \\
\hline Cleeve (Ireland) Itd & $\mathrm{Y}$ & - & - & - & - & $19 / 05 / 1927$ & & $14 / 02 / 1929$ \\
\hline X.L Dairies & $\mathrm{N}$ & 121 & 5 & 24.20 & 0.00 & $18 / 08 / 1927$ & & $20 / 12 / 1928$ \\
\hline Irish milk products & $\mathrm{N}$ & 2 & 2 & 1.00 & 0.00 & $10 / 08 / 1929$ & & \\
\hline The Royal Meath Dairy Itd & Gen & 2000 & 5 & 400.00 & 100 & $08 / 08 / 1934$ & & $05 / 10 / 1943$ \\
\hline
\end{tabular}

Sources: Dissolved company files: D 1134, 1323, 1380,2020, 2151,2424, 2480, 2871, 4755, 4921, 6143, 6148, 6154, 6168, 7027, 7082, 7159, 7252, 7611, 7620, $7645,7909,8757$ 
Table 4: Cow and creamery density, 1892, 1901 and 1908

\begin{tabular}{|c|c|c|c|}
\hline & 1892 & 1901 & 1908 \\
\hline & \multicolumn{3}{|c|}{ Milch cows per square mile } \\
\hline Leinster & 31.19 & 30.84 & 30.83 \\
\hline Munster & 60.17 & 63.11 & 65.89 \\
\hline Ulster & 54.52 & 54.23 & 52.65 \\
\hline \multirow[t]{2}{*}{ Connaught } & 30.52 & 31.90 & 32.31 \\
\hline & \multicolumn{3}{|c|}{ Cooperatives per 10,000 square miles } \\
\hline Leinster & 7.93 & 21.14 & 36.99 \\
\hline Munster & 37.62 & 72.01 & 117.14 \\
\hline Ulster & 0.00 & 117.84 & 181.57 \\
\hline \multirow[t]{2}{*}{ Connaught } & 0.00 & 39.35 & 62.06 \\
\hline & \multicolumn{3}{|c|}{ Creameries per 10,000 square mile } \\
\hline Leinster & 46.23 & 71.33 & 56.80 \\
\hline Munster & 141.86 & 374.00 & 393.35 \\
\hline Ulster & 6.01 & 138.28 & 215.24 \\
\hline \multirow[t]{2}{*}{ Connaught } & 4.54 & 45.41 & 84.76 \\
\hline & \multicolumn{3}{|c|}{ Creameries per 10,000 Milch cows } \\
\hline Leinster & 1.48 & 2.31 & 1.84 \\
\hline Munster & 2.36 & 5.93 & 5.97 \\
\hline Ulster & 0.11 & 2.55 & 4.09 \\
\hline Connaught & 0.15 & 1.42 & 2.62 \\
\hline
\end{tabular}

Sources: Agricultural Statistics of Ireland, 1892, 1901, 1908. 
Map 1: Creameries in Ireland, 1908

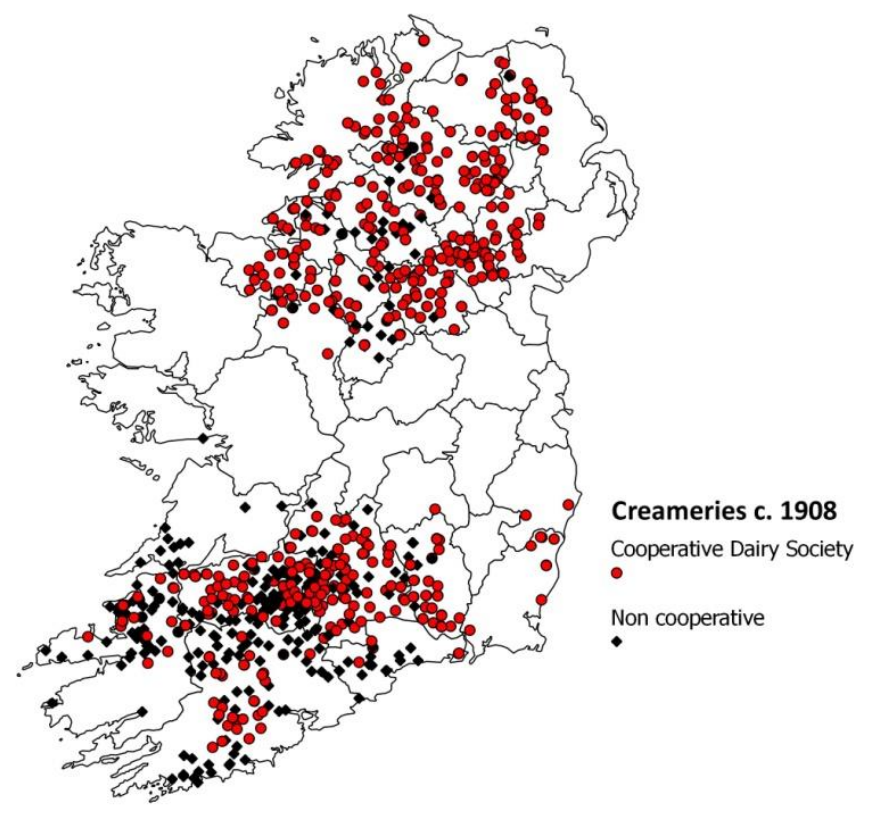

Source: Source for cooperatives: IAOS annual report 1908 and Porter (n.d./1909); source for noncooperatives Porter (n.d./1909). 
Figure 1: Irish butter exports

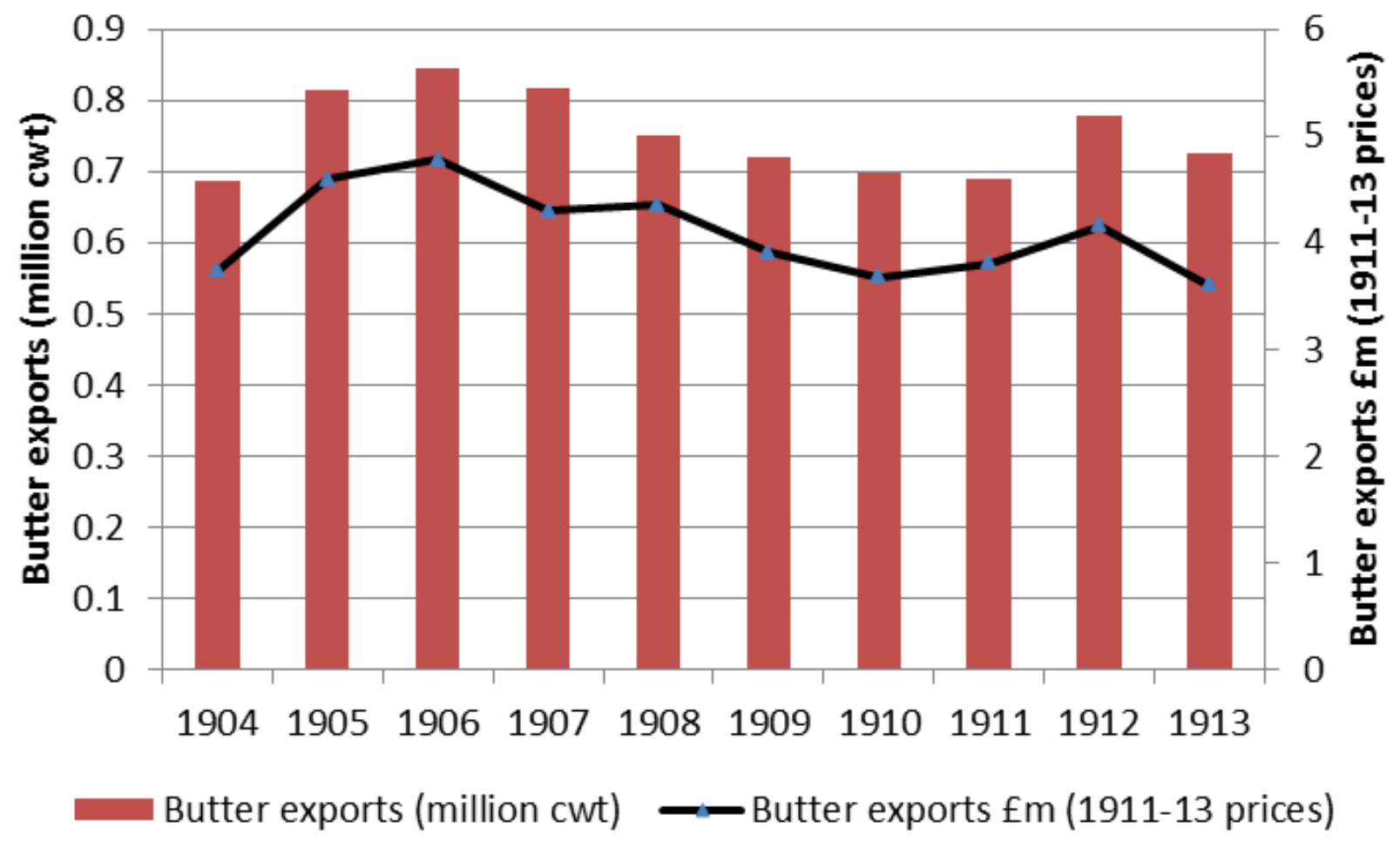

Source: DATI export statistics: Jason Begley, Frank Geary and Kevin H. O'Rourke (eds.), HNAG Database of Irish Historical Statistics (http://www.tcd.ie/iiis/HNAG/HNAG_database.htm)

Figure 2: Economics of institutions

\begin{tabular}{|c|c|c|c|}
\hline $\begin{array}{l}\text { Embeddedness: } \\
\text { informal } \\
\text { institutions, } \\
\text { customs, traditions, } \\
\text { norms, religion }\end{array}$ & $\begin{array}{l}\text { Institutional } \\
\text { environment: formal } \\
\text { rules of the game-esp. } \\
\text { property (polity, } \\
\text { judiciary, bureaucracy) }\end{array}$ & $\begin{array}{l}\text { Governance: play of the } \\
\text { game-esp. contract } \\
\text { (aligning governance } \\
\text { structures with } \\
\text { transactions) }\end{array}$ & $\begin{array}{l}\text { Resource allocation } \\
\text { and employment } \\
\text { (prices and } \\
\text { quantities; } \\
\text { incentive alignment }\end{array}$ \\
\hline
\end{tabular}

Source: Williamson (2000, p. 597). 